\title{
PRISON CAMP NO. 29 FOR PRISONERS OF WAR FROM THE SECOND WORLD WAR ON THE TERRITORY OF KAZAKHSTAN BETWEEN 1943-1949
}

\author{
Aimar Ventsel, Baurzhan Zhanguttin
}

\begin{abstract}
This article is the first publication of materials about Pakhta-Aral prison camp No. 29 for prisoners of war. The fate of prisoners of war (both Western and Eastern) remains largely unclear. One reason is because the camps for prisoners of war were subordinated to an extremely closed and classified structure - the GUPVI. To some extent, Pakhta-Aral was an untypical prison camp in the Soviet prison camp system. While most prison camps were established to support industry or resource extraction with labour, then a far smaller number of prison camps were connected to agriculture. The Pakhta-Aral camp was opened as a workforce supply for the cotton growing collective farms of Kazakhstan. Interestingly, archival data show that the need to supply the camp with food and clothes added some liberal aspects to camp life. Some researchers argue that prison camps were a model for the so-called 'non-Gulag' society, but the Pakhta-Aral camp shows that at least some civic practices were adopted where they helped to improve the functioning of the camp.
\end{abstract}

Keywords: Gulag, Kazakhstan, Pakhta-Aral, prisoners of war, repressions

One of the unresolved mysteries of the history of the Second World War was the fate of 3,120,944 prisoners of war on the territory of the Soviet Union, including 1,836,315 Germans, 637,000 Japanese, 425,549 Hungarians, 121,590 Austrians, and also representatives of other nationalities. The reason for the uncertainty was the fact that information about the destiny of prisoners of war was guarded by one of the most closed and classified structures, known only by a circle of experts - the Administration for the Affairs of Prisoners of War and Internees (Upravlenie po delam voennoplennykh $i$ internirovannykh, renamed in 1944 as the Main Administration for the Affairs of Prisoners of War and Internees or Glavnoe upravlenie po delam voennoplennykh I internirovannykh, GUPVI). This institution was subordinated to the infamous NKVD - MVD SSSR or Narodnyi Komissariat Vnutrennykh Del or People's Commissariat of Internal Affairs - a Soviet ministry for internal affairs). By the end of 1945, 
the structure of the GUPVI contained 267 prison camps that included 3200 branches (lagernye otdeleniia), 392 labour battalions (rabochii batal'on) and 178 'special hospitals'; these facilities were located across the whole territory of the former Soviet republics (Karner 2002: 286).

Difficult access to the data is probably one, but certainly not the only, reason why research on Soviet prison camps seldom focuses on foreign prisoners. For example, two recently published collections of articles on the Gulag (Kritika 16 (3), 2015; Laboratorium 7 (1), 2015), cutting edge literature without doubt, include no paper on prisoners of war (see also Applebaum 2003; Barnes 2011). Institutionally, the Gulag was a separate structure independent of the GUPVI; however, the camps did not differ substantially. ${ }^{1}$ This article attempts to contribute to the public knowledge of foreign prisoners of war in the territory of the Soviet Union, both during and after World War II.

Research on the Gulag as a topic has produced an impressive body of literature, despite the fact that these studies emerged in the West in the early 1970s (Alexopoulos 2015: 470). There are different authors with different positions in the field, but only few researchers have studied prison camps in their complexities. The short history of the camp under scrutiny reveals some interesting practices and unexpected features of Stalinist camp life. By examining these early unpublished materials, the Gulag camp appears as a complex structure with its own internal dynamics, unexpected to the reader accustomed to the image of the Gulag as a brutal and monolithic prison camp system. The data reveals that the development of a camp included the co-existence of several ethnic groups, various economic practices and subordination lines. When Khlevniuk and Belokowsky (2015) write that the Gulag became a model of organisation for the 'outside' world - non-Gulag - then our data indicates the opposite process: in order to run the camp with minimum obstacles, the administration adopted or allowed many practices characteristic of the civil society.

This article focuses on only one camp, the Pakhta-Aral prison camp No. 29 for prisoners of war and internees. We wish to illuminate some key moments and facts from the history of the camp and, finally, publish the names of people who died and were buried in the camp. The material in the article is drawn from newly discovered and previously unpublished documents from various archives of the Republic of Kazakhstan, found between 2012 and 2014.

During World War II, and in its aftermath, 49,000 prisoners of war - former officers and soldiers of the German, Italian, Romanian, Finnish, and Japanese armies - were sent to the territory of Kazakhstan. This 'contingent' was kept in prison camps subordinated to the GUPVI (Zhanguttin 2008). Prison camp No. 29 opened in March 1943 by the decree No. 00398 of the NKVD, dated the 1st of March of the same year. By that decree the camp was located in the South- 
Kazakhstan oblast (Iuzhno-Kazakhstanskii oblast), 90 kilometres from the city of Tashkent and 14 kilometres from the Syr-Dar'inskaia railway station, which was a station on the Tashkent railway line on the territory of a cotton raising collective farm ${ }^{2}$ Pakhta-Aral. The main purpose for establishing the camp was to carry out the construction of a water canal for future cotton fields, to provide them with an enormous amount of water. This connection with agriculture makes camp No. 29 untypical. As a rule, Stalinist prison camps were created to support mining or other industries with workforce. In order to satisfy the process of industrialisation with food and other resources, the NKVD simultaneously established camp complexes with an agricultural focus. One difference between such Gulag camps and camps for prisoners of war was that when in the first case the camp administration was able to pick up prisoners with a required professional profile, then there is no such evidence of the GUPVI camps practicing a similar procedure.

\section{THE BEGINNING}

As with most Stalinist prison camps, camp No. 29 was divided into several smaller camps or 'departments'. Six such 'departments' were placed alongside the planned water canal route with a distance of between 3 and 15 kilometres from their future worksites. All these camp units were established by two decrees of the NKVD: No. 00398B from the 1st of March 1943, and No. 001409 from the 13th of August 1943. ${ }^{3}$

Each of the camp units had not only a number but also a name: No. 1 was the unit named after Felix Dzerzhinsky (the legendary head of the VTsK (Vserossiiskaia chrezvychainaia komissiia, All-Russian Emergency Commission), a security police service established by the Bolsheviks during the October Revolution and the predecessor of the NKVD), No. 2 bore the name of Komintern (an international Communist organisation, controlled by the Soviet Union), No. 3 was called Il'ich (the patronymic of Lenin), No. 4 - Stalin, No. 5 - Pervomaiskii (or the First of May), and No. 6 - Oktiabr'skii (October - in honour of the October Revolution).

The archival data does not reveal the exact date when the first echelons with prisoners arrived, but it is clear that the establishment of the camp did not go smoothly. The official archival documents state that prisoners of war captured at Stalingrad arrived without the support of medical personnel and the necessary medicaments. The 'contingent' was exhausted and full of lice, suffering from spotted typhus. The result of the echelons arriving in such a condition 
was that 1,632 German prisoners of war died of dystrophy and spotted typhus (Karner 2002: 48).

Simultaneously, the contingent in the camp constantly increased. After the German prisoners of war other nationalities arrived - Italian, Japanese, and so forth. These groups were sent to Pakhta-Aral around 1944, after mass surrenders and sentencing of enemy soldiers (Shirokorad 2010: 294; Ursu 2009: 104). To house such a number of people, prisoners of war were forced to build barracks. Residential and supplementary buildings in camp No. 29 were mainly barracks built of adobe and framed reed. It seems that contrary to many other Gulag camps, residential buildings in the Pakhta-Aral camp complex had more room for inmates, with scant but still existing comforts like bedding and a bath within close walking range. As the accounting documents state, "Because of local climatic conditions, this type of construction is quite suitable for living". ${ }^{4}$ Each barrack housed 70 to 120 prisoners of war; the space allocation was three square metres of living space per person. The barracks were equipped with plank beds, and each prisoner of war was also provided with bedding. All the camp units included so-called bathing-laundry blocks, basically bath houses with a capacity to bathe twenty-five men in one hour simultaneously, cleaning their clothes in primitive disinfection chambers. Typical of Stalinist prison camps, the Pakhta-Aral camps were surrounded with an approximately two and a half metre high barbed wire fence.

\section{FEEDING THE CAMP}

Looking closer at the archival records, it becomes obvious that life in the PakhtaAral camp units predominantly focused on the constant need to find additional sources of food. Theoretically, the headquarters of the Central-Asian military district supplied the camp with all types of needed goods. As it appears from documents, the German army contingent that arrived at the end of March 1943 was suffering from exhaustion and was therefore provided with enhanced supplementary feeding. Apart from the food provided according to Gulag norms, prisoners of war also gathered wild edible plants. In 1943, 28.8 tons of sorrel and $230 \mathrm{~kg}$ of various mushrooms were gathered. In 1943, a supplementary farm (podsobnoe khoziaistvo) was organised in camp No. 29, which had approximately 20 hectares of territory for growing watermelons, melons, and other suitable agricultural crops. Later on, this supplementary farm became an important source for the camp complex food supplies. The farm also provided the 'contingent' with additional vegetables and products of animal husbandry. The importance of the farming activities is obvious because the territory of the 
farm quickly grew to 153 hectares in 1946. Substantially, in order to grow more, all the fields were irrigated. The discovered data is impressive and shows how much was harvested and turned over to the authorities. In 1946 the 'production' included 1,503 centners of potatoes, 14,687 centners of vegetables and fruits, and 1,411 centners of maize and rice. Interestingly, the camp administration allowed certain groups to collect their own food in order to cook their national cuisine (natsional'nye bliudy). This fact demonstrates a certain liberalism, allowing "non-Gulag practices" (Khlevniuk \& Belokowsky 2015) to enter into the Gulag. The Italians and the French, for example, were allowed to use turtles and frogs for food. During one year, the prisoners harvested 10.6 tons of turtles and approximately $1000 \mathrm{~kg}$ of frogs. ${ }^{5}$ As a consequence, the use of turtles and frogs for food significantly reduced the cost of feeding prisoners. The costs of maintaining the camp were further reduced when prisoners began to make footwear in the camp, wearing light boots and sandals instead of factory produced footwear in the summer. ${ }^{6}$ Consequently, it could be argued that one of the main concerns for the administration was to find new ways to utilise local resources in order to reduce spending. For that purpose, a certain liberalism and elements of civil life were tolerated.

\section{ORGANISING 'NORMALITY’ IN THE CAMP}

After the opening of the camp, the administration tried to establish a working routine, a certain kind of 'normality'. The purpose of the Pakhta-Aral camp complex was to provide a workforce for the agricultural collective farm, and, as mentioned above, not especially unusual, but still a rather rare use of a Gulag prison camp, which usually provided cheap labour for industrial or resource extraction enterprises like factories or mines.

During the establishment period of camp No. 29 there was a lack of transport; the number of horses and automobiles was clearly insufficient. As a consequence, the camp administration decided to purchase horses at Skotoimport (Cattle Import), and by the end of 1944 there were 14 cars and 52 horses in the camp that fully met the needs of its economy. ${ }^{7}$

Prisoners of war were used for agricultural work in the cotton fields. The extant documents confirm in typical Soviet bureaucratic language:

At the beginning, because of the lack of skilled workers in the production apparatus of the camp and experience in organising labour, as well as [lack of] guidance from the centre, the productivity and wages of the prisoners of war were very low from 1943-1944. According to the incomplete data 
for 1943, of 2082 [prisoners] listed for labour, only 811 people or $39 \%$ received salaries. The average daily output per one norm-day ${ }^{8}$ was equal to 3 roubles and 44 kopecks, and labour productivity in the whole camp was only $59.2 \% .^{9}$

This is one of the rare documents proving that the financial motivation of prisoners also existed in camps for foreigners. Wages were introduced during the war in order to increase productivity of an otherwise non-motivated forced labour. Some researchers argue that although wages did have their impact, the overall effect was rather low (Rossi 1989: 455-457; Khlevniuk 2004: 338-339).

Guarding of prisoners of war was carried out by the soldiers from the 223rd military convoy regiment, whose headquarters was located six kilometres from the camp. The main communication between the camp management and commandeers of the military unit was conducted by telephone. To make guarding of prisoners more efficient, search dogs were kept in four of the camp administration department offices. Entry to the zone of the camp unit territory was permitted strictly only with temporary or permanent entry permits (propusk). The standard size of the military convoy when taking prisoners out of the camp for work was three guards for twenty-five prisoners. Often the camp administration set additional posts in places favourable for escape. Not unusual for the Soviet prison camp system was that inmates were sometimes used as guards. In his essay, Alan Barenberg advocates the concept of 'dezonification' of the Gulag, where there was no spatial distance between the prisoners, camps, and civil population (Barenberg 2015). Pakhta-Aral was no exception. The guarding of prisoners and running the economy was a process that built a certain bridge between the Gulag and non-Gulag personnel. In addition to military staff, three support teams from among the loyal and proven prisoners were formed. These teams served as guards both inside the camp and during the work tasks outside.

Within the radius of 25 kilometres around the camp complex a security zone was established, where entrance was forbidden to any unauthorised persons. In the security zone 65 'reaction brigades' (brigady sodeistvia) were formed, whose task was to search for, and capture, escaped inmates. In an emergency, the brigades could be called immediately into action, or to 'react', hence the title. The 293 persons who were members of those brigades were volunteers from among the Communist Party and collective farm activists. During the whole camp history, prisoners made only 17 attempts to escape. In 15 cases runaways were arrested. In one case one escapee attempted to swim across the River Syr-Daria and drowned. The last runaway has been counted since 1945 as being escaped, and has not been found. There is, however, reason to believe that he, also, was killed in an accident. ${ }^{10}$ 


\section{THE CLOSING PROCESS}

The decision to begin the process of closing Pakhta-Aral camp was announced with a decree of the NKVD of the USSR No. 00348 addressed to the "peoples' commissar of internal affairs of the Kazakh SSR, to the commissar of the state security, comrade Bogdanov", informing him that "the sixth camp complex of the NKVD, camp No. 29, shall be liquidated". ${ }^{11}$ Looking at the wording of the decree, it becomes clear that the local power structures had very little impact on whether, and how, camps were established on their territory. As was the case with the opening of the Pakhta-Aral, the closing of the camp was decided in Moscow, and the local government just had to accept it. However, the process of liquidation did not go as smoothly as planned. The difficulties are indicated by the content of the NKVD decree No. 001035 from the 11th of September 1945. The decree announced that 40,000 Romanian prisoners of war should be released from the camps of the GUPVI NKVD. More precisely, in the same decree an order was given to release 230 prisoners of war as part of the postWorld War II repatriation policy. The ultimate fate of these released prisoners is unknown. It is known that they were sent "to the territory of Romania via railway through the station of Ungheni, and further over the sea through the ports of Crimea as well as Odessa, Nikolaev, and Novorossiisk, until they reached Constanța (a seaport on the Black Sea coast of Romania)". ${ }^{12}$

Every released prisoner of war was entitled to receive a document of their release confirmation "signed by the head of the camp, as it was formulated by the decree of the NKVD No. 00955 from the 13th of August 1945". ${ }^{13}$ The policy of repatriation foresaw "sending released prisoners of war to their homeland forming echelons and [using] individual wagons, following the assigned [poputnye] routes, accompanied by officers and guards from camps, in small parties by [the most] direct route - [also using] passenger trains under the guard of the officers of the camps". The decree also called for concentrating repatriating prisoner groups in the "most convenient" place to form bigger groups and send them to Constanța. "The released Romanian prisoners of war should be accompanied by medical personnel having a sufficient reserve of medicines; the prisoners should also be provided with food for the path."14

On the 27th of September, 1945, decree No. 001097 was issued, according to which camps number 42,43 , and 47 were to be liquidated. By the same decree, "in order to bring the limit capacity of prison camps for the Germans into accordance with the actual presence of these prisoners of war", instructions were given to "reorganise the existing camps and their camp units for guarding the prisoners of war". The decrees established a new "limit capacity" of 7,000 people for the NKVD camp No. 29 "at the state farm ${ }^{15}$ of Pakhta-Aral in the 
South Kazakhstan region", to be housed in six camp departments: a thousand people in Nos. 1, 2, 3, and 6, and 1,500 prisoners in departments No. 4 and $5 .{ }^{16}$

In 1947 the remaining units of the Pakhta-Aral camp No. 29 were disbanded.

Based on the orders of the Ministry of Internal Affairs of the USSR No. 00234 from the 3rd of March, 1947, and No. 00528 dated the 19th of May, 1947, camp branches No. 1, 4, and 6 were to be closed. German prisoners of war, kept in the camp, were supposed to be transported to the Spaso-Zavodskii camp No. 99 (to be engaged in coal industry). The Japanese prisoners of war were to be transferred to the Almaty camp. The closing report states that "at the time of the dissolution of the camp, the phys[ical] state of Japanese prisoners of war transferred to camp No. 40 is characterised as follows: category $1-1,532$ people; category $2-506$ people; category $3-90$ people. Disabled -11 people. $\mathrm{OK}^{17}-26$ people. Sick - 60 people". ${ }^{18}$

In the terminology of the NKVD, the first category of prisoners of war were "practically healthy, fit to perform heavy physical work"; the second category were "partially fit for physical labour, with chronic diseases or disabilities"19; the third category meant that the prisoners were fit only for light physical work, having serious chronic illnesses or physical disabilities; the fourth category included disabled people. After the "discharge [razgruzka] of the camp" by the order of the Ministry of Internal Affairs of the USSR No. 0069 from the 24th of January, 1948, the camp management and camp units No. 2, 3, and 5 were disbanded..$^{20}$

\section{MORTALITY}

The Gulag system is associated with the suffering of prisoners, and the camp under study was no exception. As the archival data shows, from the very beginning of the Pakhta-Aral prison camp No. 29, the authorities had to deal with high mortality rates. One reason was the catastrophic condition of the infrastructure during the war years. The transport of prisoners from Stalingrad started in January 1943 but faced serious problems like a destroyed railway network, a lack of wagons and locomotives. Documents show that in some cases German prisoners of war were loaded into wagons that waited a week or more for the locomotives. Most prisoners of war arrived, therefore, in poor health, suffering from cold and hunger. German prisoners of war reveal in their memoirs that during the first weeks of capture they were afflicted by hunger as were almost all the people they encountered: 
By digging in the black earth of fields I found a few almost hard potatoes. We boiled them a long time in a small kettle until they transformed into porridge. The colour [of the porridge] was black with slightly blue streaks; it was a non-appetising mass, crunching between our teeth. But it felt so delicious. (Sokolov 2003)

According to estimations of German scholars, one-fifth of the 3,000 German prisoners of war sent to Pakhta-Aral from Dubrovka in European Russia in 1943 died in transit (Karner 2002: 48).

The high mortality of German prisoners also concerned the Soviet officials who put the blame on malnutrition. On the 28th of May, 1943, the officers of the NKVD of the Kazakh SSR sent the following report to Moscow:

Moscow, NKVD. To Kruglov. During the last five days, on May 21-25, [1943], twelve people died in the Pakhta-Aral prison camp No. 29 for prisoners of war. The cause of the deaths is in all cases the lack of protein. This is confirmed by the pathoanatomical opening of the corpses. The opening shows an absolute lack of fat layer under the skin, atrophy of muscles [a longer list of symptoms indicating that prisoners suffered from severe hunger follows]. There are another 60 people in the camp who suffer from the lack of protein. [---] In accordance with the findings, the provision in the camp will be reorganised corresponding to the norms of the last decree No. 25/2329. The camp is stocked with the required food items, with the exception of dried fruits, potatoes, milk, and vegetables. Bogdanov. ${ }^{21}$

Due to a mass outbreak of typhus, the medical service of the camp had to cooperate with the medical officials of the Kazakh SSR in order to conduct prophylactic work among the prisoners of the camp, and also among the ordinary workers of the collective farm. The situation was so dramatic that officials of the highest level had to intervene. A telegram dating from the 11th of December, 1943, was received in the capital of the KSSR, Alma-Ata. It was addressed to the commandant of prison camp No. 29 and informed him that the catastrophic situation with high mortality in the camp had worried the commissar of the state security of the NKVD, comrade Bogdanov. The high NKVD official was disturbed that, notwithstanding the 'substantial help' provided by the NKVD in Moscow, 30 prisoners died in Pakhta-Aral camp in October 1943, 27 in November, and 7 prisoners within the first ten days of December..$^{22}$

By the end of December, 1943, the NKVD of the USSR issued an order No. 001860. The text of the order criticised the chief of the prison camp, major of security service Dukhovnyi, for the "lack of initiative, mismanagement, inability 
to organise and provide health welfare in camps", which had resulted in a high contraction of illnesses by Italian prisoners of war during the last months. By this order, major Dukhovnyi was removed from office and degraded to a lower post. The decree also appointed a new chief for camp No. 29, Lieutenant Colonel Sorokin, who was transferred to the office from the position of the chief of prison camp No. 99. Sorokin received a strict order to "take decisive action for the full implementation of directives from the NKVD about the therapeutic measures among prisoners". ${ }^{23}$

The camp administration, alongside the medical staff, reacted quickly in order to prevent a huge loss of life among the prisoners of war. At each of the six camp departments infirmaries were organised, systematically carrying out preventive treatment among prisoners. The camp administration also imposed strict control over the sanitary condition of the premises, thus avoiding the spread of infectious diseases. This all eventually allowed the situation in the camp to improve.

The documents allow us to understand the extent of mortality in the camp. In 1943 , it was 1,862 people, in 1944 - 86 people, in 1945 - 53 people, in 1946 38 people, and 16 people in 1947. In general, reporting data from various camps differs. In some documents it was recorded that "during the existence of the camp [No. 29] 2,055 people died, among them 1,998 Germans and 57 Japanese"; in another document, the total figure amounts to $20,072 .{ }^{24}$

By the order of the GUPVI NKVD of the Soviet Union, About the Burial of Prisoners of War, dating from the 24th of August, 1944, instructions were given for the procedure concerned with the disposal of the dead prisoners. The camp administration was obliged to "establish in the immediate vicinity of the camp or [camp] hospital special areas of free land". ${ }^{25}$ The land had to be fenced off with barbed wire and divided into squares. Each square had to be divided into five rows of graves with five graves in each row. On each grave it was necessary to erect an identification mark - a strong pole with a wooden disk nailed to the top of the pole, carrying a number of the grave and the square.

In order to account for the deceased prisoners of war and their places of burial, it was necessary to have a special cemetery book, which was supposed to contain the following information about the deceased: their last and first name, date of birth, nationality, military rank, date of death and date of burial, the number of the grave and the square in which they had been buried. The cemetery book was also accompanied by the plan of the cemetery, mapping the location and numbers of squares, and the numbers of existing graves (Mikheeva 2005: 97).

The archives of the Russian State Military Archive (RGVA) preserved data on prisoners of war buried in the cemetery of the Pakhta-Aral camp No. 29. 
Precise data on the exact number of the deceased could not be found. From the documents it appears that "a proper burial in accordance with the order of the Ministry of Internal Affairs of the USSR was introduced only in October 1944. Until this time, 1,944 people were buried, but the cemetery where they were buried does not currently [18th June 1949 - dating of the document] exist". ${ }^{26}$ And it continues further in dry Soviet bureaucratic language:

By questioning the old workers in the camp, it was ascertained that in 1943 a typhus epidemic raged, and in connection with the high mortality rate of prisoners of war, they were buried in different places, and in large mass graves. These tombs are now ploughed over and planted with vegetable crops, or in connection with the expansion of the construction of the camp, outbuildings have been built. It is not possible to restore the old cemetery. ${ }^{27}$

In addition, from the documents dated the 18th of June, 1949, it appears that graveyards of camp units No. 1 and 4 are "left without supervision and now the cemetery is defunct. Identification signs have been destroyed on some graves, other graves are overgrown with weeds; if we do not take action, the cemetery will be completely destroyed". ${ }^{28}$

Researcher S. Bukin, in his studies on the Germans who returned from Soviet captivity, has provided detailed descriptions of how the burials were conducted:

Between the end of September 1944 and the moment I was sent home on September 5, 1947, I changed camp four times, but still remained on the outskirts of the city of Novosibirsk. Thank God that I did not get sick. I was sent to outside work on a daily basis: to a factory for the production of ammunition, to laying railway lines, to the collective farm, to the galvanic station of radio works. Due to the long working hours (during the war more than 12 hours, and the way there and back an additional hour and a half; later on the average working time with coming and going was 10 hours), and in part to the very hard work and malnutrition after returning to the camp, we were tired as dogs, fell on boards and no one thought about each other. So I cannot satisfy any inquiries about names. With regard to mortality, as far as I know, in the winter of 1944-1945, ten people in our camp died every day from malnutrition and dysentery. They were buried far away from any property, in the tundra, without names and the installation of grave crosses. Three times that winter I myself was a digger of large graves. We made only one temporary cross out of wood from packing cases for our colleagues and set it there. (Bukin 2001: 200)

This kind of burial was typical for prisoners of war, and happened also in a similar way in other Gulag camps. 


\section{CONCLUSION}

Over the entire period of its existence, that is, from March 1943 to February 1948, camp No. 29 housed in total 10,649 prisoners, among them 8,321 people from the Western armies of Hitler's coalition and 2,328 people who were Easterners. Documents about the camp complex were found in different archives, but the picture of the life and functioning of Pakhta-Aral still remains incomplete. There is a great deal of unclarity about the short history of the camp, as well as about the identity of its prisoners. Research on Pakhta-Aral and similar camps helps to fill a gap in the research of Stalinist prison camps for prisoners of war. As stated by British anthropologist Vieda Skultans, "Much of what happened in the Gulag has been left unrecorded, unexamined, and unexpiated" (Skultans 2015: 109). Due to high classification and subordination to another structure (GUPVI), Soviet camps for prisoners of war have been less studied than Gulag camps for their 'own people'. Various archives of Kazakhstan and Russia preserve documents allowing us to learn more about the fate of foreign military personnel and the camps they were kept in. Some of these documents are still hard to find because files are scattered over several archives, distributed between Russia and Kazakhstan, and very often poorly catalogued. Therefore, luck is a friend of the researcher who is interested in learning more about the long-forgotten camps for prisoners of war.

\section{APPENDIX $^{29}$}

\section{List of buried prisoners of war in the cemetery of Pakhta-Aral prison camp No. 29}

\section{Camp unit 1}

\begin{tabular}{|l|l|l|l|l|l|l|}
\hline No. & $\begin{array}{l}\text { Surname, name, } \\
\text { patronymic }\end{array}$ & $\begin{array}{l}\text { Date of } \\
\text { birth }\end{array}$ & $\begin{array}{l}\text { Military } \\
\text { rank }\end{array}$ & $\begin{array}{l}\text { Date of } \\
\text { death }\end{array}$ & $\begin{array}{l}\text { Date of } \\
\text { burial }\end{array}$ & Nationality \\
\hline 1 & $\begin{array}{l}\text { Privedela, } \\
\text { Giuseppe } \\
\text { Angelo }\end{array}$ & 1921 & soldier & 04.10 .1944 & 05.10 .1944 & Italian \\
\hline 2 & $\begin{array}{l}\text { Kiodi, Edoardo } \\
\text { Nauzarenno }\end{array}$ & 1914 & soldier & 08.10 .1944 & 08.10 .1944 & Italian \\
\hline 3 & $\begin{array}{l}\text { Spampati, } \\
\text { Cuarrino Andr. }\end{array}$ & 1917 & $\begin{array}{l}\text { sen. } \\
\text { sergeant }\end{array}$ & 11.10 .1944 & 11.10 .1944 & Italian \\
\hline
\end{tabular}


Prison Camp No. 29 for Prisoners of War from the Second World War

\begin{tabular}{|c|c|c|c|c|c|c|}
\hline 4 & $\begin{array}{l}\text { Pisocia, Mateo } \\
\text { Vincenzo }\end{array}$ & 1921 & corporal & 20.10 .1944 & 20.10 .1944 & Italian \\
\hline 5 & $\begin{array}{l}\text { Cecetini, } \\
\text { Giovanni } \\
\text { Gustavo }\end{array}$ & 1918 & $\begin{array}{l}\text { sen. } \\
\text { corporal }\end{array}$ & 20.10 .1944 & 20.10 .1944 & Italian \\
\hline 6 & $\begin{array}{l}\text { Marketti, } \\
\text { Umberto Primo }\end{array}$ & 1915 & soldier & 18.01 .1945 & 19.01 .1945 & Italian \\
\hline 7 & $\begin{array}{l}\text { Silvestri, Bruno } \\
\text { Angel Ait. }\end{array}$ & 1914 & soldier & 16.04 .1945 & 16.04 .1945 & Italian \\
\hline 8 & $\begin{array}{l}\text { Farkash, } \\
\text { George Ioi }\end{array}$ & 1916 & $\begin{array}{l}\text { sergeant } \\
1 \text { st class }\end{array}$ & 10.08 .1945 & 10.08 .1945 & Russian \\
\hline 9 & $\begin{array}{l}\text { Werner, } \\
\text { Wilhelm }\end{array}$ & 1913 & sergeant & 02.09 .1945 & 03.09 .1945 & German \\
\hline 10 & $\begin{array}{l}\text { Iakonetto, } \\
\text { Antonio George }\end{array}$ & 1919 & & 26.12 .1943 & 26.12 .1943 & Italian \\
\hline 11 & $\begin{array}{l}\text { Apostoe, Petr } \\
\text { Teodorv }\end{array}$ & 1916 & & 01.01 .1944 & 01.01 .1944 & Italian \\
\hline 12 & $\begin{array}{l}\text { Ripaldi, Antonio } \\
\text { Horacio }\end{array}$ & 1917 & & 01.01 .1944 & 01.01 .1944 & Italian \\
\hline 13 & $\begin{array}{l}\text { Toldi, Nikolai } \\
\text { Iosif }\end{array}$ & 1913 & & 01.01 .1944 & 01.01 .1944 & Italian \\
\hline 14 & $\begin{array}{l}\text { Verrastro, } \\
\text { Giuseppe Franz }\end{array}$ & 1922 & & 08.01 .1944 & 08.01.1944 & Italian \\
\hline 15 & $\begin{array}{l}\text { Govanelo, } \\
\text { Eugilo Rocco }\end{array}$ & 1909 & & & 09.01 .1944 & Italian \\
\hline 16 & $\begin{array}{l}\text { Raito, Mario } \\
\text { Mario }\end{array}$ & 1914 & & & 14.01 .1944 & Italian \\
\hline 17 & $\begin{array}{l}\text { Viscontini, } \\
\text { Antonio Gaitan }\end{array}$ & 1912 & & & 24.01 .1944 & Italian \\
\hline 18 & $\begin{array}{l}\text { Girogori, } \\
\text { Giovanni Giov. }\end{array}$ & 1921 & & & 19.04 .1944 & Italian \\
\hline 19 & $\begin{array}{l}\text { Gambaro, } \\
\text { Vittario George }\end{array}$ & 1920 & & & 16.06 .1944 & Italian \\
\hline 20 & $\begin{array}{l}\text { Cardinali, } \\
\text { Fernando Cez. }\end{array}$ & 1909 & & & 13.07 .1944 & Italian \\
\hline
\end{tabular}




\section{Camp unit 2}

\begin{tabular}{|c|c|c|c|c|c|}
\hline No. & $\begin{array}{l}\text { Surname, name, } \\
\text { patronymic }\end{array}$ & $\begin{array}{l}\text { Date of } \\
\text { birth }\end{array}$ & Military rank & $\begin{array}{l}\text { Date of death/ } \\
\text { burial }\end{array}$ & Nationality \\
\hline 1 & $\begin{array}{l}\text { Degrementis, } \\
\text { Luigi Nadzareno }\end{array}$ & 1921 & soldier & 27.09 .1944 & Italian \\
\hline 2 & $\begin{array}{l}\text { Bucci, Rinelmo } \\
\text { Antonio }\end{array}$ & 1920 & corporal & 13.01 .1944 & Italian \\
\hline 3 & $\begin{array}{l}\text { Fabro, Ottavio } \\
\text { Antonio }\end{array}$ & 1921 & corporal & 05.11 .1944 & Italian \\
\hline 4 & $\begin{array}{l}\text { Guarnieri, } \\
\text { Angelo Augusto }\end{array}$ & 1916 & sergeant & 11.12 .1944 & Italian \\
\hline 5 & $\begin{array}{l}\text { Agacci, Gino } \\
\text { Alfredo }\end{array}$ & 1922 & soldier & 17.12 .1944 & Italian \\
\hline 6 & $\begin{array}{l}\text { Picci, Enco } \\
\text { Domenico }\end{array}$ & 1920 & soldier & 16.01 .1944 & Italian \\
\hline 7 & $\begin{array}{l}\text { Polcelli, } \\
\text { Generoso Luigi }\end{array}$ & 1921 & sergeant & 07.02 .1945 & Italian \\
\hline 8 & $\begin{array}{l}\text { Uder, Johann } \\
\text { Johan }\end{array}$ & 1910 & exempted & 17.02 .1945 & German \\
\hline 9 & $\begin{array}{l}\text { Rabustelli, } \\
\text { Giuseppe } \\
\text { Stefano }\end{array}$ & 1921 & corporal & 19.02 .1945 & Italian \\
\hline 10 & $\begin{array}{l}\text { Brahm, Franz } \\
\text { Wilhelm }\end{array}$ & 1905 & sergeant & 20.02 .1945 & German \\
\hline 11 & $\begin{array}{l}\text { Antenore, } \\
\text { Vittore Leopoldo }\end{array}$ & 1922 & private & 20.03 .1945 & Italian \\
\hline 12 & $\begin{array}{l}\text { Neudecker, } \\
\text { Eduard Adam }\end{array}$ & 1914 & sergeant & 20.09 .1945 & German \\
\hline 13 & $\begin{array}{l}\text { Arkip, Ion } \\
\text { George }\end{array}$ & 1916 & corporal & 30.03 .1945 & Romanian \\
\hline 14 & $\begin{array}{l}\text { Di Carlo, } \\
\text { Dameniko } \\
\text { Antonio }\end{array}$ & 1921 & soldier & 02.04 .1945 & Italian \\
\hline 15 & $\begin{array}{l}\text { Di Carlo, Petro } \\
\text { Felice }\end{array}$ & 1913 & soldier & 02.04 .1945 & Italian \\
\hline 16 & $\begin{array}{l}\text { Pascale, } \\
\text { Gaetano Luigi }\end{array}$ & 1922 & soldier & 11.04 .1945 & Italian \\
\hline
\end{tabular}


Prison Camp No. 29 for Prisoners of War from the Second World War

\begin{tabular}{|c|c|c|c|c|c|}
\hline 17 & $\begin{array}{l}\text { Prie, Toma } \\
\text { Toma }\end{array}$ & 1908 & soldier & 11.04 .1945 & Romanian \\
\hline 18 & $\begin{array}{l}\text { Botani, Ireneo } \\
\text { Luigi }\end{array}$ & 1921 & soldier & 25.04 .1945 & Italian \\
\hline 19 & $\begin{array}{l}\text { Levisticci, Oscar } \\
\text { Paulo }\end{array}$ & 1911 & sen. sergeant & 26.04 .1945 & Italian \\
\hline 20 & $\begin{array}{l}\text { Ferrari, Angelo } \\
\text { Paul }\end{array}$ & 1923 & sergeant & 04.04 .1945 & Italian \\
\hline 21 & $\begin{array}{l}\text { Batrinu, } \\
\text { Constantin Ion }\end{array}$ & 1921 & soldier & 27.05 .1945 & Romanian \\
\hline 22 & $\begin{array}{l}\text { Sassi, Angelo } \\
\text { Mario }\end{array}$ & 1922 & soldier & 29.05 .1945 & Italian \\
\hline 23 & $\begin{array}{l}\text { Sorrentino, } \\
\text { Vicenzo Angelo }\end{array}$ & 1920 & soldier & 02.06 .1945 & Italian \\
\hline 24 & $\begin{array}{l}\text { Agostini, Bruno } \\
\text { Amus }\end{array}$ & 1914 & soldier & 02.06 .1945 & Italian \\
\hline 25 & $\begin{array}{l}\text { Goricci, } \\
\text { Archimede } \\
\text { Ricardo }\end{array}$ & 1916 & soldier & 03.06 .1945 & Italian \\
\hline 26 & $\begin{array}{l}\text { Montanini, } \\
\text { Luigi Filiberto }\end{array}$ & 1922 & corporal & 06.06 .1945 & Italian \\
\hline 27 & $\begin{array}{l}\text { Mazante, Rafael } \\
\text { Olinto }\end{array}$ & 1917 & soldier & 11.06 .1945 & Italian \\
\hline 28 & $\begin{array}{l}\text { Rubagotti, } \\
\text { Faustino } \\
\text { Samuele }\end{array}$ & 1917 & soldier & 02.07 .1945 & Italian \\
\hline 29 & $\begin{array}{l}\text { Ravacol, Giulio } \\
\text { Guerino }\end{array}$ & 1916 & soldier & 06.07 .1945 & Italian \\
\hline 30 & Nad, Lazlo Lajoz & 1914 & exempted & 15.07 .1945 & Hungarian \\
\hline 31 & $\begin{array}{l}\text { Mala, Ferenz } \\
\text { Sandor }\end{array}$ & 1913 & soldier & 17.07.1945 & Hungarian \\
\hline 32 & $\begin{array}{l}\text { Balestrini, } \\
\text { Armando } \\
\text { Giobatta }\end{array}$ & 1920 & soldier & 22.08 .1945 & Italian \\
\hline 33 & $\begin{array}{l}\text { Imazhura, } \\
\text { Soochi }\end{array}$ & 1913 & soldier & 26.08 .1946 & Japanese \\
\hline 34 & Hasakawa, Ivao & 1910 & sen. sergeant & 01.09 .1946 & Japanese \\
\hline
\end{tabular}




\begin{tabular}{|l|l|l|l|l|l|}
\hline 35 & $\begin{array}{l}\text { Nakasima, } \\
\text { Diuken }\end{array}$ & 1906 & exempted & 09.11 .1946 & Japanese \\
\hline 36 & $\begin{array}{l}\text { Homada, } \\
\text { Sigedzhi }\end{array}$ & 1920 & soldier & 19.11 .1946 & Japanese \\
\hline 37 & Sekezima, Iogi & 1910 & soldier & 16.12 .1946 & Japanese \\
\hline 38 & Baba, Madao & 1914 & sergeant & 25.12 .1946 & Japanese \\
\hline 39 & Konno, Sodzhi & 1927 & soldier & 20.01 .1947 & Japanese \\
\hline 40 & $\begin{array}{l}\text { Takeyama, } \\
\text { Eslnou }\end{array}$ & 1923 & soldier & 21.01 .1947 & Japanese \\
\hline 41 & Masuda, Tadao & 1905 & soldier & 29.05 .1947 & Japanese \\
\hline 42 & $\begin{array}{l}\text { Tanaka, } \\
\text { Chuchasaku }\end{array}$ & 1912 & sen. soldier & 26.07 .1947 & Japanese \\
\hline 43 & Mori, Cucceo & 1902 & soldier & 05.11 .1947 & Japanese \\
\hline
\end{tabular}

\section{Camp unit 3}

\begin{tabular}{|l|l|l|l|l|l|}
\hline & $\begin{array}{l}\text { Surname, name, } \\
\text { patronymic }\end{array}$ & $\begin{array}{l}\text { Date of } \\
\text { birth }\end{array}$ & Military rank & $\begin{array}{l}\text { Date of death/ } \\
\text { burial }\end{array}$ & Nationality \\
\hline 1 & $\begin{array}{l}\text { Bertalis, Pelino } \\
\text { Luigi }\end{array}$ & 1920 & soldier & 07.10 .1944 & Italian \\
\hline 2 & $\begin{array}{l}\text { Ambrogio, } \\
\text { Giuseppe } \\
\text { Vincenzo }\end{array}$ & 1917 & soldier & 24.10 .1944 & Italian \\
\hline 3 & $\begin{array}{l}\text { Uloti, Aristide } \\
\text { Angelo }\end{array}$ & 1913 & soldier & 13.12 .1944 & Italian \\
\hline 4 & Bou, Giulio Giulio & 1914 & soldier & 24.12 .1944 & Italian \\
\hline 5 & $\begin{array}{l}\text { Radin, Francesco } \\
\text { Anako }\end{array}$ & 1915 & sen. corporal & 28.12 .1944 & Italian \\
\hline 6 & $\begin{array}{l}\text { Shira, Giacomo } \\
\text { Francesco }\end{array}$ & 1921 & soldier & 01.01 .1945 & Italian \\
\hline 7 & $\begin{array}{l}\text { Ruggi, Silvio } \\
\text { Francesco }\end{array}$ & 1922 & soldier & 03.01 .1945 & Italian \\
\hline 8 & $\begin{array}{l}\text { Verardo, } \\
\text { Augustino Batisto }\end{array}$ & 1918 & soldier & 04.01 .1945 & Italian \\
\hline 9 & $\begin{array}{l}\text { Rernoks, August } \\
\text { Autustovich }\end{array}$ & 1921 & sergeant & 07.01 .1945 & German \\
\hline
\end{tabular}




\begin{tabular}{|c|l|l|l|l|l|}
\hline 10 & $\begin{array}{l}\text { Boffa, Lorenzo } \\
\text { Bartolomeo }\end{array}$ & 1921 & soldier & 07.04 .1945 & Italian \\
\hline 11 & $\begin{array}{l}\text { Gussani, } \\
\text { Giuseppe Franz }\end{array}$ & 1911 & sen. corporal & 22.03 .1945 & Italian \\
\hline 12 & $\begin{array}{l}\text { Sinezi, Savino } \\
\text { Nikola }\end{array}$ & 1922 & soldier & 26.04 .1945 & Italian \\
\hline 13 & $\begin{array}{l}\text { Benazzato, Gus } \\
\text { Ollido }\end{array}$ & 1921 & soldier & 30.04 .1945 & Italian \\
\hline 14 & $\begin{array}{l}\text { Greco, Antonio } \\
\text { Fedele }\end{array}$ & 1922 & soldier & 23.05 .1945 & Italian \\
\hline 15 & $\begin{array}{l}\text { Emma, Tonio } \\
\text { Rocco }\end{array}$ & 1921 & corporal & 24.05 .1945 & Italian \\
\hline 16 & $\begin{array}{l}\text { Orlando, Antonio } \\
\text { Francesci }\end{array}$ & 1917 & soldier & 26.06 .1945 & Italian \\
\hline 17 & $\begin{array}{l}\text { Sfellazza, } \\
\text { Dominico Salv. }\end{array}$ & 1921 & corporal & 17.07 .1945 & Italian \\
\hline
\end{tabular}

\section{NOTES}

1 On the 6th of November, 1929, the Central Executive Committee and the Council of People's Commissars passed a law that imprisonment of up to three years should be carried out in 'regular prisons', whereas confinement from three to ten years should take place in prison camps in remote regions of the country (Prokopchuk 2004). The establishment of a network of prison camps was begun. For the management of the camp system the Gulag (Glavnoe upravlenie ispravitel'no-trudovykh lagerei, trudovykh poselenii i mest zakliucheniia or the Main Administration of Labour Camps, Labour Settlements, and Places of Detention) was created, which was subordinated to the NKVD of the Soviet Union. The Gulag controlled, in its heyday, 36 of the so-called 'corrective-labour camps' (sing. ispravitel'no-trudovoi lager'); in fact, each of these camps was a conglomerate of several prison camps (Dulatbekov 2010; Gavrilova 2003). The Gulag was officially closed on the 25th of January, 1960 (Ivanova 2006).

2 Soviet agriculture was organised in state-governed farms. A collective farm or kolkhoz was theoretically a collective property of its workers whereas a state farm or sovkhoz was a state property. Collective farm workers were able to elect their chairman whereas state farm directors were appointed by the regional ministry of agriculture. In fact, differences between these two kinds of farms were nominal.

3 GARF, f. 9401, op. 1a, d. 137, 1. 183.

4 GARF, f. 9401, op. 1a, d. 137, 1. 183.

5 RGVA, f. 1/p, op. 15a, d. 73, 1. 12. 
6 RGVA, f. 1/p, op. 15a, d. 73, 1. 12.

7 RGVA, f. 2, op. 17, d. 3, 1. 5 .

8 The norm-day was a Soviet work-cum-salary unit which had a fixed price. A worker had to complete a certain amount of work in order to be entitled to a certain amount of income. The monthly salary was a sum of completed norm-days.

9 RGVA, f. 2, op. 17, d. 3, 2.

${ }^{10}$ RGVA, f. 1/p, op. 15a, d. 73, 1. 11.

${ }^{11}$ GRAF, f. 9401, op. 12, d. 176.

${ }^{12}$ GRAF, f. 9401, op. 1a, d. 180, 1. 106, 107, 108.

${ }^{13}$ Ibid.

${ }^{14}$ Ibid.

${ }^{15}$ In some documents the prison camp is referred to as a state farm (sovkhoz). The reason for that is probably because agriculture determined the function of the prison camp.

${ }^{16}$ GRAF, f. 9401, op. 1a, d. 180, 1. 106.

${ }^{17} \mathrm{OK}$ was a category of prisoners too weak for work. They were housed in a special barrack and provided with additional feeding until they were healthy enough to go to work.

${ }^{18}$ No. 99 RGVA, f. 1/p, op. 15a, d. 73, l. 12.

${ }^{19}$ No. 99 RGVA, f. 1/p, op. 15a, d. 73, l. 13.

${ }^{20}$ Ibid.

${ }^{21}$ RGVA, f. 1/p. op. 9 v.d. 3, L. 88.

${ }^{22}$ RGVA, f. 1/p. op. 9 v.d.3, L. 120.

${ }^{23}$ GARF, f. 9401, op. 1, d. 675, 1. 490.

${ }^{24}$ RGVA, f. 24p, op. 26, d. 42, 1. 32.

${ }^{25}$ RGVA, f. 1/p, op. 05e, d. 135, l. 1.

${ }^{26}$ Ibid.

${ }^{27}$ RGVA, f. 1/p, op. 05e, d. 135, 1. 1.

${ }^{28}$ RGVA, f. 1/p, op. 05e, d. 135, l. 1.

${ }^{29}$ The data are based on archival documents: RGVA, f. 1/p, op. 05e, d. 135, 1. 9, 10, l. 136, 1. 10, 11, 12; 1. 137, 1. 10. 


\section{ARCHIVAL SOURCES}

GRAF $=$ Gosudarstvennyi arkhiv Rossiiskoi Federatsii (State Archive of the Russian Federation)

RGVA = Rossiiskii gosudarstvennyi voennyi arkhiv (Russian State Military Archive)

\section{REFERENCES}

Alexopoulos, Golfo 2015. Destructive-Labor Camps: Rethinking Solzhenitsyn's Play on Words. Kritika: Explorations in Russian and Eurasian History, Vol. 16, No. 3, pp. 499-526. DOI: 10.1353/kri.2015.0045.

Applebaum, Anne 2003. Gulag: A History. New York \& London \& Toronto \& Sydney \& Auckland: Doubleday.

Barenberg, Alan 2015. The Gulag in Vorkuta: Beyond Space and Time. Laboratorium, Vol. 7, No. 1, pp. 92-108. Available at http://www.soclabo.org/index.php/ laboratorium/article/view/426, last accessed on January 13, 2016.

Barnes, Steven A. 2011. Death and Redemption: The Gulag and the Shaping of Soviet Society. Princeton: Princeton University Press.

Bukin, Sergei S. 2001. Zakhoroneniia voennoplennykh v Novosibirskoi oblasti. [Burial Sites of Prisoners of War in the Novosibirsk Oblast.] In: V. Shishkin (ed.) Aktual'nye problemy sotsial'no-politicheskoi istorii Sibiri (XVII-XX vv.): Bakhrushinskie chteniia 1998 g. [Topical Problems of Socio-Political History of Siberia (17th-20th Centuries): Bakhrushins Readings of 1998.] Novosibirsk: Novosibirsk State University, pp. 192-205.

Dulatbekov, Nurlan (ed.) 2010. Karlag: neubet zhyldardyn zhazylmas zharasy (estelikter) = Karlag: vechnaia bol' surovykh vremen (vospominaniia) = Karlag: Endless pain of hard times (memoirs). Karagandy: Arko.

Gavrilova, Evgeniia 2003. Memorial Karagandy. Karlag, kul'tura, khudozhniki. [Karaganda Memorial: Kalag, Culture, Artists.] Karagandy: TOO Arko.

Ivanova, Galina 2006. Istoriia GULAGa, 1918-1958: sotsial'no-ekonomicheskii i politikopravovoi aspekty. [The History of GULAG, 1918-1958: Socio-Economic and Political-Legal Aspects.] Moskva: Nauka.

Karner, Stefan 2002. Arkhipelag GUPVI: Plen i internirovanie v Sovetskom Soiuze 1941-1956. [Archipelago GUVPI: Prisoners and Internment in the Soviet Union 1941-1956.] Trans. by O. Aspisova. Moskva: RGGU. Available at http://www. ex.ua/12216644, last accessed on January 13, 2016.

Khlevniuk, Oleg 2004. The History of the Gulag: From Collectivization to the Great Terror. New Haven, CT: Yale University Press.

Khlevniuk, Oleg \& Belokowsky, Simon 2015. The Gulag and the Non-Gulag as One Interrelated Whole. Kritika: Explorations in Russian and Eurasian History, Vol. 16, No. 3, pp. 479-498. DOI: 10.1353/kri.2015.0043.

Mikheeva, Liudmila 2005. O zakhoroneniiakh plennykh vtoroi mirovoi voiny v Tsentral'nom Kazakhstane. [About the Burial Sites of Prisoners of the Second World War in Central Kazakhstan.] Aus Sibirien-2005: nauchno-informatsionnyi 
sbornik. Tiumen': Izdatel'sko-poligraficheskii tsentr Ekspress, pp. 95-98. Available at http://library.ikz.ru/georg-steller/aus-sibirien-2013-2005/miheeval.v.-karaganda-kazahstan-o-zahoroneniyah, last accessed on January 13, 2016.

Prokopchuk, Stanislav 2004. Bunt v Kengire. [Rebellion in Kengir.] Newspaper Trud, No. 121, July 1. Available at http://www.trud.ru/article/01-07-2004/73852_bunt_v_ kengire.html, last accessed on March 9, 2016.

Rossi, Jacques 1989. The Gulag Handbook: An Encyclopedia Dictionary of Soviet Penitentiary Institutions and Terms Related to the Forced Labor Camps. Trans. by William A. Burhans. New York: Paragon House.

Shirokorad, Aleksandr 2010. Italiia: Vrag ponevole. [Italy: Enemy against Will.] Moskva: Veche.

Skultans, Vieda 2015. Afterword. Laboratorium, Vol. 7, No. 1, pp. 109-113. Available at http://www.soclabo.org/index.php/laboratorium/article/view/508/1309, last accessed on January 12, 2016.

Sokolov, Boris 2003. Stalingradskaia pobeda i sud'ba nemetskikh plennykh. [The Victory of Stalingrad and the Destiny of German Prisoners of War.] Available at http://grani.ru/Society/History/m.21371.html, last accessed on January 14, 2016.

Ursu, Dmitrii 2009. Odesskii tranzit 1945 goda: repatriatsiia frantsuzskikh voennoplennykh iz SSSR. [Odessa Transit in 1945: Repatriation of French Prisoners of War from the USSR.] Iugo-Zapad: Odessika, Vol. 9, pp. 103-118. Available at http://dspace.onu.edu.ua:8080/handle/123456789/2116, last accessed on January 14, 2016.

Zhanguttin, Baurzhan 2008. GUPVI: voennoplennye i internirovannye na territorii Kazakhstana (1941-1951 gg.). [GUVPI: Prisoners of War and Internees on the Territory of Kazakhstan (1941-1951).] Otechestvennaia istoriia, Vol. 2, pp. 107-114. 